\title{
NORMING THE FEMALE BODY: DISCOURSES OF SEXUALITY IN DANTE GABRIEL ROSSETTI, CHRISTINA ROSSETTI AND ALGERNON CHARLES SWINBURNE
}

\author{
Normalización del cuerpo femenino: Discursos de la sexualidad en Dante Gabriel Rossetti, \\ Christina Rossetti y Algernon Charles Swinburne
}

\author{
Lai Sai Acón Chan*
}

\begin{abstract}
RESUMEN
Este artículo explora las contradicciones resultantes de un discurso sexual construido en el siglo XIX a partir de un modelo sexual hegemónico que determina los rígidos roles sexuales de la sociedad victoriana inglesa. Se analizan algunas obras literarias de Dante Gabriel Rossetti, Christina Rossetti y Charles Swinburne a la luz de estas problemáticas.

Palabras clave: Hermandad de los Pre-Rafaelitas, ideología de la creación literaria, políticas sexuales victorianas, la mujer caída, la mujer nueva.
\end{abstract}

\begin{abstract}
This article explores the contradictions resulting from sexual discourse constructed in the nineteenth century from a hegemonic model that determines sexual rigid sex roles of Victorian English society. Some literary works of Dante Gabriel Rossetti, Christina Rossetti and Charles Swinburne related with these issues are discussed.

Key Words: Pre-Raphaelites, Ideology of Literary Creation, Victorian sexual politics, Representations of women, Fallen Woman, Lily/Rose Dichotomy, New Woman.
\end{abstract}

Universidad de Costa Rica. Escuela de Lenguas Modernas, Costa Rica.

Correo electrónico: lacon567@yahoo.com

Recepción: 01/07/13. Aceptación: 17/09/13. 
"It has been portrayed as the era when rigid puritanism allied with moral hypocrisy, verbal and visual delicacy marched arm in arm with a flourishing pornography. The authoritarian paterfamilias presided over the institutionalisation of the double standard, while the pedestalised mother and wife depended for her purity on the degradation of the fallen woman. It was an age when sex was publicly, indeed ostentatiously denied, only to return, repressed, to flourish in the gentle undergrowth." Jeffrey Weeks on the Victorian age

The contradictions underlying the moral code of the Victorian era reflected power struggles that led to the shaping and reshaping of sexual identities. As Weeks points out in Sex, Politics and Society: The Regulation of Sexuality since 1800, the Victorian age was one of "harsh and repressive sexual Puritanism"; meanwhile "the debate about sexuality exploded" and it "became a major social issue in Victorian social and political practice" (19). As propriety dictated, prostitution was euphemistically referred to as a "social evil," while gonorrhea and syphilis, as the "social diseases" (19). Yet, according to several studies, "the alternative (or profession) of prostitution [was] a cultural sign of the Victorian era's avid fascination with the harlot ${ }^{1}$ " (Casteras 131). Thus, romanticized images of fallen women proliferated in cultural productions as those of "the seduced girl, adulterous wife, kept mistress, courtesan, harlot, or common prostitute" (Marsh 77). It is my aim in this article to link discourses of power and sexual politics in the late Victorian period and representations of the female body among the Pre-Raphaelites and their associates. An evolution, although illusory, of the fallen woman figure will be traced from the works of Dante Gabriel Rossetti to those of his sister, Christina, to those of Charles Algernon Swinburne, in order to illustrate the varied ways in which they partook in the ongoing debate about sexuality and the insidious ways in which hegemonic structures allow a certain degree of deviance from the established discourse on sexuality.
While D.G. Rossetti perpetuates the subjection of a dichotomous female body by patriarchy, C.G. Rossetti and Charles Algernon Swinburne provide different signifieds to the body of the fallen woman in their attempts, however failed, to overcome hegemonic structures of power.

Shortly after the publication of Michel Foucault's seminal work, The History of Sexuality, Weeks concurs with Foucault in that the Western experience of sex is "a constant, and historically changing, deployment of discourses on sex" and the history of sexuality, "a history of our discourses about sexuality"( 7). Recent Victorian criticism also acknowledges the influence of The History and, more specifically, the sexual politics of the era. In the introduction to Sexualities in Victorian Britain (1996), Andrew H. Miller and James Eli Adams contend that by entitling his opening chapter "We 'Other Victorians," Foucault challenged prevalent Freudian theories about sexuality as a libidinal force governing human behavior. For Miller and Adams, Foucault's work is "most widely and influentially associated with the view that sexuality is best understood as a construction of regulatory systems, rather than an elemental force subject to repression [. . .]. Sexuality thus understood is not a biological imperative but an intricately articulated array of political identities constructed out of imperatives to believe, to feel, to act" (4).

For Lloyd Davis, in Foucault's examination of the history of sexuality, the nineteenth century was a crucial period in the development of a system of 'power-knowledge' through which 'a productive body and a subjected body' could be set into social motion (4). According to Davis' Virginal Textuality and Textuality in Victorian Literature (1993), the productive body is the virginal one, a body paradoxically subjected to the dominant discourse on sexuality. This productivity, therefore, coerces the female body and is expressed by means of binary oppositions: the Madonna/whore dichotomy, also known as the lily /rose or monster/angel dichotomies. Indeed, in the introduction to his book, Davis declares that "Virginity is one of the means through which societies generally translate 
sexuality as a natural and moral fact of life' into a commonsense, unquestioned mirage that becomes a "natural fact of life" (3-4). In other words, at some point in the history of human sexuality, virginity evolves into an expected, uncontested state that precludes the human ability to discern between right and wrong. It becomes naturally accepted.

In the same way, J.B. Bullen claims in The Pre-Raphaelite Body: Fear and Desire in Painting, Poetry and Criticism (1998) that "Whether the prostitute was seen as an economic, medical, or anthropological threat to the prevailing norms, or was seen as a figure who tested the limits of orthodoxy, she also acted as an enabling vehicle through which the norms could reassert themselves" (55). Thus, the mid-nineteenth representations of both the fallen woman and the virginal figure spring from a Manichean binary opposition between propriety and immorality that encapsulates the contradictions and tensions of the Victorian era.

Although Rosemary Hennessy and Judith Butler are not Victorian critics, their interpretations of Foucauldian discourse will serve to give this analysis a gendered perspective. A materialist feminist like Hennessy, part of whose work derives from her reading of Foucault's and of Judith Butler's theories about sexuality, believes that "One of the most remarkable features of the history of sexual identities is the lack of any consensus over how to understand precisely what sexuality is" $(2000,37)$. Hennessy poses some questions that address her precursors' concerns about the political nature of sex: "What is the materiality of sexuality? Is it libidinal desire? Bodies and pleasure? Discourses? Culture-ideology?" (37). Although Butler's readings of Foucault (and of other thinkers and cultural critics) serve an agenda that primarily addresses issues of feminism and, ultimately, of sexual orientation, both Butler and Foucault agree on one issue/ notion in particular: that the category of sex is normative or, in Foucauldian terminology, a "regulatory ideal" (1). Sex is "part of a regulatory practice that produces the bodies it governs, that is, whose regulatory force is made clear as a kind of productive power, the power to produce-demarcate, circulate, differentiatethe bodies it controls" (1). In the context of D.G. Rossetti, C.G. Rossetti and Swinburne, at least three discourses about sex can be traced, one regulatory and two inherently full of what Butler calls "instabilities" or "possibilities for rematerialization" (2).

Dante Gabriel Rossetti's rendering of the fallen woman is the product of faithfully adhering to the tenets of the nineteenth-century ideology of literary creation. In the fashion of a "proudly masculine cosmic Author"-in the words of Sandra Gilbert and Susan GubarRossetti poured the patriarchal ink into the passive female body, the blank page, patiently waiting to be shaped as either an angel or a monster. And in so doing, Rossetti was merely reproducing a normative view about sex. In fact, his sonnet sequence, The House of Life, can be interpreted as a metaphor of a dichotomous female body fatefully caught between the two poles of feminine behavior imposed by patriarchy. On one hand, Rossetti depicts sensuous and captivating women who only live to fulfill respectable roles as brides, wives, or mothers. These are the kind of women who know what it means "To be a sweetness more desired than Spring; / A bodily beauty more acceptable" ("True Woman"). The descriptions of the women in the sonnets are indicative of the gender norms of the era, "High grace," "sweet simplicity," "thrilling pallor of cheeks," "a mouth whose passionate forms imply / All music and all silence held thereby," "soft-stirred feet" ("Her Gifts"), "Sweet dimness of her loosened hair," "sweet hands," tremulous smiles," "murmuring sighs," "The confident heart's still fervour," "the swift beat/ And soft subsidence of the spirit's wing" ("Love-Sweetness"). However, the women's intellectual traits are never praised.

To give the women the illusion that they are the ones with power in the relationship, the male speakers resort to royal treatment: "My lady's absolute queendom" ("The Moonstar"), "lady, beams thy sovereign grace,/ When the drear soul desires thee" ("Gracious Moonlight"). On the other hand, a fallen woman like Lilith 
represents the darker side of the mid-Victorian woman. And yet, she has this irresistible power to allure men, which rather than threatening the ideological apparatus supports it. In “Body's Beauty" Lilith's sexuality can be described as mature and intoxicating, but sweet and, therefore, desirable to Adam. She does not destabilize normative sexual practices but embodies male fantasies of women who sensuously take over their bodies with a "sweet tongue [that] could deceive" and "strangling golden hair" $(3,14)$. Adam's weakness lies not in her power to emasculate him, but in his own willingness to let her engulf him with her wealth of hair and enrapture him to the point of ecstasy. So The House of Life is Rossetti's figurative rendering of the female body regulated by the dominant, midVictorian sexual politics; it is also a metaphor of the repressive house that encloses that body.

Not only in The House of Life but also in individual poems like "The "Blessed Damozel," "Mary's Girlhood," "Jenny," "The Orchard Pit," "Eden Bower," and "Sister Helen" does Rossetti develop the lily/rose motifs that inevitably enclose women within the prisons of their own bodies. In the context of the ideology of literary creation, the desirable type of woman, the eternal feminine, only fulfills roles that are imposed on her mainly because of her biological and domestic circumstances. Thus, she is the virginal bride, or the loving wife, or the selfless mother, or the asexual widow. And if she remains unmarried, she is expected to dedicate herself to a life of seclusion in a convent or become a respectable yet sexless old maid. On the other hand, the fallen type of woman is the one who has forsaken either her proper place within the house or her virginity and is, therefore, considered a whore, whether she actually sells her body or not. So, Rossetti's women fit two clear-cut labels. While the Blessed Damozel, the Virgin Mary, and some of the women in House belong in the first category, Jenny, Sister Helen, Lilith, and the woman from the Orchard Pit are the fallen women or femmes fatales of the second category.

The lily is the ideal type of woman who submits to every patriarchal whim and never replies impertinently or belligerently. In this respect, Gilbert and Gubar point out that, "There is a long and crowded road from The Booke of Curtesye (1477) to the columns of 'Dear Abby,' but social historians have fully explored [the conduct book's] part in the creation of those 'eternal feminine' virtues of modesty, gracefulness, purity, delicacy, civility, compliancy, reticence, chastity, affability, politeness [. . .] (23). Rossetti certainly has a penchant for representations of demure women. One of the techniques he employs in his poems is that of imposing the male speaker's thoughts and feelings on the women's, thus, producing phallocentric readings. In "The Blessed Damozel," the lover is described as an omniscient being, while the damozel has a limited apprehension of her world. While he seems to know her every thought and movement, what she wears and what she says, she spends her time in heaven longing for her beloved and wondering when he will be able to join her. Like the proverbial angel in the house (Coventry Patmore's "Angel in the House"), she is restricted to the domestic sphere-heavenand patiently awaits his arrival as a dutiful wife would wait for her husband. In the meantime, she smiles, looks sweet and innocent with her lilies in her hand, the stars in her hair, and makes endless plans for their life together in paradise. This, however, is the lover's version since the damozel is represented in the poem as he pictures her in heaven.

Another lily is the Virgin Mary in "Mary's Girlhood." She is in fact described as an "angel-watered lily" (10) who like a blank page awaits with "devout respect,/ Profound simplicity of intellect,/ And supreme patience" (4-6) to be filled with the patriarchal ink that would inscribe her as the mother of God. Other idealized feminine representations appear in House as either a bride who passionately nurses love in her soul just like a mother would lovingly gaze at her newborn baby ("Bridal Birth" 1-4)), or as a woman whose beauty can only be compared to the genius of creators ("Genius in Beauty"). What all these women have in common is their eagerness to fulfill 
patriarchal expectations of an impossible eternal feminine secluded in the prison of the female body. The damozel is caught in the immaturity of a virginal, childish body whose desires must necessarily parallel the purity of her new abode. "Because the fullness of the time was come" ("MC" 14), Mary becomes a captive of her biological clock and is expected to give birth to God made flesh. The bride is expected to fulfill her wifely role passionately enough to satisfy the sexual appetite of her lord, a "creature of poignant thirst/ And exquisite hunger" ("BB" 5-6), just as a mother is supposed to become a selfless vessel for the desires of her children. And the lady with a "sovereign face" ("GB" 7) and a "power [that] shall wreak no wrong" (14) is nothing but the essence of what patriarchy believes to be beautiful and, thus, good and true.

In Dante Gabriel Rossetti's artistic works, the rose is, on the other hand, the type of woman who refuses those traditionally submissive roles but still pleases men with her "deviant" sexuality, a perverse sexuality that can only pertain to the fallen woman. The overt sexuality of women like Jenny, the woman in "The Orchard Pit," and Lilith is not abhorred, but rather desired by men. Although a fallen woman, Jenny is akin to the angel in the house. She embodies the perfect mix of lily and rose, which is even more attractive than the devout angel in the house. With her "wealth of loosened hair," "silk ungirdled and unlac'd" and "warm sweets open to the waist," Jenny represents an all-but-innocent and virginal woman; but rather than adopting an overly forward attitude that one would expect from a harlot, she submissively puts her head on the male speaker's knees. To further romanticize the fallen woman figure, like the sexual politics of his time dictated, Rossetti devotes a whole stanza to soften, even condone, Jenny's profession. She is then compared to "a rose shut in a book / In which pure women may not look" (253-254), and to a "rose / Puddled with shameful knowledge" whose blood "flows / Through leaves no chaste hand may unclose" (264-66). Both images evoke an inner beauty that cannot be tarnished by such a shameful practice since the rose "still keeps such faded show / Of when t'was gathered long ago, / That the crushed petals' lovely grain, / The sweetness of the sanguine stain" (267-270).

Unlike Jenny, Sister Helen, Lilith, and the demonic female from "The Orchard Pit" are portrayed as sex goddesses or as femmes fatales. In "Sister Helen," Rossetti tells the tragic tale of a sorceress who puts a spell on a former lover due to spite and resentment,

'He calls your name in an agony,

Sister Helen,

That even dead Love, must weep to see.'

'Hate, born of Love, is blind as he

Little Brother.'

(O Mother, Mary Mother,

Love turned to hate, between Hell and Heaven!) (162-68)

After jilting her for a woman more suitable to be his bride, Keith of Ewern meets an untimely demise in the hands of the enchantress. Gradually, his internal fire is consumed just as Helen's voodooed waxen man melts away, and she avenges herself in a fatalistic end that portends her own damnation: "'Ah! What is this that sighs in the frost?'/ 'A Soul that is lost as mine is lost"" (290-91). Likewise, in "The Orchard Pit," Rossetti depicts a threatening woman with "Life's eyes [. . .] gleaming from her forehead fair / And from her breasts the ravishing eyes of death" (14). That is, a dark goddess from the underworld. Yet the male lover seems to find solace in the embrace of this Hadean femme fatale: "My love I call her, and she loves me well" (16). Equally paradoxical is Lilith, an archetypal terrible mother whose voluptuousness casts a difficult-to-break spell on Adam: "Not a drop of her blood was human, / But she was made like a soft sweet woman" ("Eden Bower" 3-4). Drawn to the type of women who are compellingly feminine and seductive if not beautiful ${ }^{2}$, Rossetti found an artistic outlet in this combination of angel and whore. He exploited the images of the submissive and compliant, yet dangerously alluring, female body and made it an object of the dominant sexual politics of the Victorian age. Thus, his representations of women can be said to be 
unreal and reveal the inner workings of the oppressive ideology of literary creation of the nineteenth century. No wonder why women in that century were often suffering from all kinds of ailments; they were expected to be either angels trapped within the house of patriarchy or fallen women who had gone astray on the path leading to that house.

About Rossetti's renderings of both the virginal woman and the fallen woman, Bullen asserts that the inconsistencies, uncertainties, and contradictions of his work "are just a reflection of similar inconsistencies within the culture at large" (58). He contends that the female body was "then point of intersection between purity and pollution [. . .] the fallen woman had a double and powerful hold on the mid-Victorian imagination, simultaneously repellent and exciting, engendering both pity and loathing [like Jenny]" (58). Because he was essentially a sensualist and a true disciple of the doctrine of Art for Art's Sake, rather than a participant in debates over social issues of his time, Rossetti hedonistically reproduced the sexual politics and the ideology of literary creation of his century. As Bullen notes, "The female is denied agency at all points. Her appearance, her past, her present aspirations, her future desires and ambitions, her attitudes to herself and her attitudes to the male are all constructs of the male consciousness" (66).

While Dante Gabriel's works were true to nineteenth-century ideology of literary creation, Christina Rossetti's representations of the midVictorian female body challenge the normative notions about sexuality embodied by her brother's angels and monsters. She transforms the dominant definition of the Victorian fallen woman in her depictions of a woman who, dis-eased with her biological circumstances, provides the seed for the 1890s New Woman, someone akin to the madwoman who thinks for herself, has a career and a story to tell, seeks internal enlightenment, challenges accepted ideas, and creates artistic works (Moi 58). Actually, in The Madwoman in the Attic Gilbert and Gubar contend that the literature of the nineteenth century portrays female characters and reveals female authors who apparently develop illnesses on purpose to purge their guilt, denounce their anger, find an outlet for their desires, or express their self-worth. In Bloomian terms, women writers in particular suffer from a kind of anxiety of influence, which when transposed to the realm of female creativity causes women an anxiety of authorship, "an anxiety built from complex and often only barely conscious fears of that authority which seems to the female artist to be by definition inappropriate to her sex" (Gilbert 51). Many of these groundbreaking women becoming precursors in fields traditionally dominated by men, put such a strain on them that their bodies, circumscribed by the "regulatory ideal," produced diseases such as claustrophobia, agoraphobia, amnesia, aphasia, madness, and eating disorders, to further constrain them and keep them in their proper place. However, in many cases, argue Gilbert and Gubar, the female bodies reappropriated those maladies and turned them into dis-eases, that is, ways to signal nonconformity to sexual norms of the time.

In her attempts to transcend pre-fixed, essentialist labels, Rossetti portrays the female body as agonizingly trying to reshape itself, particularly through supernatural means. Her use of the preternatural in works such as "Goblin Market," some of her ghost poems, some of her death poems, and stories like "Maude," "Nick," "The Lost Titian," and "Hero" put in evidence the female body's desire to escape the patriarchal prison of the flesh. In "Goblin Market," Lizzie and Laura are portrayed as two sweet maidens who are destined to fulfill social expectations as respectable wives and mothers, but before reaching patriarchy's ideal state they have a taste of some supernatural fruits that transmute their bodies. The only one to give in to temptation, Laura awakens to the supernatural power of the forbidden goblin fruit. She turns "most like a leaping flame" (218), sitting at night in "a passionate yearning,/And gnash[ing] her teeth for baulked desire" (266-67). It seems as if her body were accepting the newfound nymphomaniac passion and struggling against 
years of repression in, and confinement to, the domestic sphere. Laura even begins to neglect her domestic chores:

She no more swept the house,

Tended the fowls or cows,

Fetched honey, kneaded cakes of wheat,

Brought water from the brook:

But sat down listless in the chimney-nook

And would not eat. (293-98)

In fact, Laura's ingestion of the fruit juices and, later on, her refusal to feed her body point at eating disorders that might signal nonconformity with her body. Her eagerness to suck the fruit juices from her sister's face also supports this theory since it takes on unsuspected and "perverse" homoerotic dimensions. Laura clings to Lizzie almost desperately, kisses her with her hungry mouth over and over until her lips scorch, tears off her clothes, and finally falls, "Pleasure past and anguish past" (522). For a brief moment, Laura is able to transcend patriarchal labels in a most supernatural or rather unnatural way by behaving like a bulimarexic, lesbian nymphomaniac, but in the end she conforms to social expectations by getting married and bearing children. However, Laura still has a story to tell about her resistance to conventional behavior and momentarily experiences a selfish indulgence only reserved for a new breed of females: the New Women who, according to Susan Casteras, made [their] appearance toward the close of the century in England (144).

Another heroine who in trying to escape the prison of her body indulges herself in dreams of rematerialization and provides a model for the New Woman, is Maude. Torn between socially acceptable roles such as marriage and seclusion in a convent, Maude cannot avoid feeling guilty of the chosen path. She is burdened by a gift to write poetry that is rarely bestowed on other young women of her generation: "People thought her clever, and that her little copies of verses were handed about and admired. Touching these same verses, it was the amazement of everyone what could make her poetry so brokenhearted as was mostly the case" ("Maude" 253). Overwhelmed by the constant attention to her verse, she envies the simplicity and happiness of her cousins and friends, destined to fulfill patriarchal expectations. She constantly looks pale, "languid and preoccupied to a painful degree" (253) as a typically ill woman from the nineteenth century-in particular a female creator-must have looked like. She seems to use her malady to project the anxieties of being trapped in a normative woman's body. Unlike Laura and Lizzie, she is not destined to fulfill the role of her cousin Mary nor does she hear the call of God, like her acquaintance Magdalen. Neither embroidery nor prayer is in Maude's mind, but writing. However, writing is not a source of pleasure and tranquility, but something that reminds her of her abnormalcy in the eyes of Victorian patriarchy: "You cannot mean for the present that you will indulge in vanity and display; that you will court admiration and applause; that you will take your fill of pleasure until sickness" [. . . ] (267). And yet, unlike her successor, the literary New Woman, Maude does not flaunt convention, ruin her honor, upset her family, or refuse to repent for alleged sins. The accident that keeps Maude bedridden is a symbol of her wish to escape from her prison: "she had been overturned; and, though no limb was broken, had neither stirred nor spoken since" (270). She develops both agoraphobia and aphasia in her unconscious attempt to confront the realization that she was moving away from the normative. Since she cannot cope with the guilt of being both so talented a poet and a woman, she gradually withers away until she breaks free from the constraints of the regulatory ideal and free from labels, even from the future New Woman branding. While Maude's anxieties are not a supernatural way of transcending patriarchal expectations, they might reveal why Christina Rossetti had a proclivity for tales of transmutation and poems about ghosts and death.

Works like "Chilly Night," "The Hour and the Ghost," "The Ghost's Petition," "A Nightmare," and "At Home" are the type of poems that deal with spirits that transcended their prisons of flesh, while poems like "Death Before Dead," "After Death," "Remember," "Song," 
and "Sleeping at Last" deal with human beings who are only too glad to leave their bodies behind. Perhaps because they are narrative in nature, the ghost poems do not seem to offer clues about those spirits' former lives that made them glad they were finally set free, but it might be said that Rossetti's inclination to write about them seems to indicate that fleeting to the realm of ghosts is just one possibility to transcend the lily/rose dichotomy. Then, like the New Woman or the madwoman in the attic, these ghosts demonstrate that even those who slipped into oblivion have a story to tell, unsavory opinions, or are willing to defy conventions. Some of the ghosts come back from the afterlife to disturb those they once knew. Yet, others make themselves visible to mortal eyes because they are more disturbed than when they were among the living. "The Ghost's Petition" is the story of Robin, a spirit who, ailed by his former wife's pain, pleads her not to grieve for him anymore: "I could not rest if you would not moan / Hour after hour; I have no power to shut my ears where I lie alone" (4648) laments the ghost. In "The Hour and the Ghost," a spirit comes back from the afterlife to exact a woman's promise on her wedding day, despite her reluctance and revulsion:

Come with me, fair and false,

To our home, come home,

It is my voice that calls:

Once thou wast not afraid

When I woo'd, and said,

'Come our nest is newly made'-

Now cross the tossing foam. (11-17)

Unlike this outspoken ghost, the ghost of the speaker's mother in "A Chilly Night" speaks without a voice and stares without seeing, a sad reminder that for the friendless speaker, "Living had failed and dead had failed/And [she/he] was indeed alone" (49-50). The ghost "At Home" returns to her/his old house only to discover her/ his friends in lively gatherings: "'Tomorrow,' said they, strong with hope,/And dwelt upon the pleasant way,/'Tomorrow' cried they one and all,/While no one spoke of yesterday" (1720). That is, the former self of the ghost was forgotten and was "Like the remembrance of a guest/That tarried but a day" (31-2). Like the troubling, yet equally troubled New Woman, the deceased people's new state in the ghost poems is sometimes welcomed. Other times the new state is despised or rejected (and by extension the New Woman), and even makes some spirits long for their previous existence.

As lyric poems, the death poems seem to be more personal and might offer more insights into Rossetti's feelings about the patriarchal prison of the flesh. In "Death Before Dead," she recognizes the stiffness of the subjected female body, "Grown hard and stubborn in the ancient mould, / Grown rigid in the sham of lifelong lies" and perhaps wishes that her condition would progress: "We hoped for better things as years would rise" (5-7). "After Death" signals a fortunate mutation in her body after what could be called the "death" of women who obeyed patriarchal injunctions and a more humane, sympathetic social perception of the women who departed from normativity: "He did not love me living: but once dead / He pitied me" (13-14). "Sleeping at Last" might be a metaphorical farewell to the female body caught in the patriarchal contradiction since in sleeping the persona would feel "No more a tired heart downcast or overcast" (5) and leave "the struggle and horror past" (2). Then, in "Song," the persona wants "no sad songs" (2) when she is gone because her departure from this world must be seen as a felicitous transmutation into a different, maybe even more desirable state. That is why she tells her loved one that whether he remembers or forgets, her former state is not important since what is important is the change itself. Finally, in "Remember," even when the female persona initially asks the loved one to remember, in the end she says, "better by far you should forget and smile / Than that you should remember and be sad" (13-14), meaning that what matters is her present state, not her past state as a fallen woman.

Stories like "Hero," "Nick," and even "The Lost Titian" further treat the theme of transmutation, even in surprisingly different ways, all pertinent to Rossetti's attempts to 
break loose from fixed gender roles. In the first story, the "beautiful, lively, tender-hearted" Hero seems to have everything a woman ever wanted: she is "the pet of her father, the pride of her neighbours, and the true love of Forss" (293). But she begins to grow apart from those who used to encompass the whole world to her and nothing seems to satisfy her: "Yet from that day forward Hero was changed; their love no longer seemed sufficient for her; she sought after other love and other admiration. Once a lily was ample head-dress, now she would heighten her complexion with a wreath of gorgeous blossoms ("Hero" 294). When a fairy princess asks her what her wish is, instead of conforming to a quiet life with her beloved, she chooses to be "the supreme object of admiration" (295) wherever she goes. This wish, however, entails a life of constant transformation and she does indeed undergo several changes: from an innocent maid to a heavy blazing diamond, to the heart of a princess, to the voice of a gifted diva, to a rose plant and, finally, back to her old body. While Hero feels the need to change and have different experiences as probably many female creators did in the nineteenth century, Nick is fortuitously granted a wish so that he could "straightway become everything [he] wish[ed]" (287). Unfortunately, he uses his new powers to spite his townsmen, but his malice and greed backfire and he is nearly buried alive. Finally, Titian's last piece undergoes some transformations throughout the centuries. The ambiguity of its subject matter is the first element that causes a changing perception from person to person since everybody speculates how it looks, but as the narrator says, "no words could have described a picture that combines the softness of a dove's breast with the intensity of an October sunset" (306). With the intention of recovering Titian's painting from his creditors, Gianni underhandedly disguises it by painting another layer on it and then claims it as one of his own paintings. However, as the Titian was taken out of his studio while still moist and since he died without revealing the secret, the painting was lost and accounted for in several legends that add more to the ambiguity. In one way or another, the three stories deal with permutations that could parallel the Victorian woman's painful need to grow apart from traditional gender roles and defy structures of power. In fact, in none of those stories is the change portrayed as an easy enterprise: distressful knowledge comes with change. Being the only Pre-Raphaelite female poet who achieved enduring fame and one among a very select sisterhood of British female poets in the nineteenth century must have put an enormous strain on Christina Rossetti. Her literary production is so eclectic both in form and in subject matter that one cannot help wonder if anxiety of authorship manifested itself in her need to address the theme of transmutation in quite a few pieces and in her wide and sometimes contradictory variety and mix of genres: the cautionary, the supernatural, the devotional; lyrical poetry, narrative poetry; autobiographical tales, folk tales, short stories, and fairy tales.

C.G. Rossetti's pre-New Woman is undeniably a source of difference and a signifier that breaks with the fixity of the lily/rose type of fallen woman. Yet, does Rosetti's unstable discourse on sexuality succeed in challenging the hegemonic discourse on sexuality? In Materialist Feminism and the Politics of Discourse, Hennessy contends that "As a construction of the feminine that circulated within and breached the cultural common sense, [the New Woman] can be read as a symptom of a more general crisis of subjectivity, an index of the disruption and recontainment of the hegemonic bourgeois ideology of the feminine" (104-105). In the context of Rossetti's pre-New Woman figure, instability and rematerialization certainly mean defiance to and disruption of sexual normativity, but they also signify a mere redefinition of the same old fallen woman. The marginal ways of transcending pre-fixed labels and the permutations of Laura, Maude, the ghosts, the dead, Hero, Nick, and the lost Titian occur only within a space defined by hegemonic thought. That is why, after a brief bout of rebelliousness, Laura and Hero take up the roles of married women, Maude dies, the ghosts, the dead and the lost Titian are forgotten, 
and Nick learns his lesson. Thus, Rossetti defies the normative discourse on sexuality with an abnormal discourse that eventually becomes normative because that is the way hegemonic structures insidiously work. The Rossetian female body agonizingly trying to reshape itself is none other than the patriarchal female body in a different shape and, therefore, in a tinsel cage.

While Chistina Rossetti's women are able to transcend patriarchal bodily restrictions (if temporarily), although not without a high dosage of guilt and excruciating pain, Swinburne's women synthesize the lily/rose dichotomy and, in doing so, they attempt to transcend Dante Gabriel Rossetti's notion of the female body as a prison and, to a certain extent, act in direct opposition to the sexual politics of the nineteenth century. On one hand, Swinburne portrays primordial goddesses or mortals who predate patriarchal labels (Hertha, Proserpine, Althea); on the other hand, he depicts figures of terrible women who have destructive powers that create everything anew (Dolores and Anactoria). His primordial beings must necessarily belong to a matriarchal world that antedates the nineteenth century women caught in the eternal contradiction of the angel/whore. Hertha is "equal and whole" (4), "man and woman" (15), "The deed and doer, the seed and sower, the dust which is God" (35), "Born, and not made" (67). And those who approach her have to "Love or or unlove [her], Unknow or know [her]" (18-19). In a strikingly similar manner, in "Atalanta in Calidon," queen Althaea is depicted as "The source and end, the sower and the scythe,/ The rain that ripens and the drought that slays,/ The sand that swallows and the spring that feeds" 2211-13). She is the loving mother of Meleager, but she is not trapped in her domestic role since she is the only one who has his destiny in her hands and the only one who gives him life and takes it away from him. In the Proserpine poems, "Hymn to Proserpine" and "In the Garden of Proserpine," Swinburne further develops the synthesis of contraries. Thus, in Proserpine's world, "silence is more than all tunes" and "the red rose is white" ("HP" 97-97), "one is tired of tears and laughter" and "life has death for neighbor" as she "gathers all things mortal/ With cold immortal hands" and "We are not sure of sorrow,/And joy was never sure; To-day will die to-morrow" ("GP" 9, 17, 51-52, 73-75). That is, Hertha, Althaea, and Proserpine embody an ambiguity that is not possible to observe in the women of Dante Gabriel Rossetti. The apparent ambiguity of Rossettian women like Jenny is Manichean since she is constructed as a being that essentially pleases patriarchy. In this Rossettian world, the rose figure contradicts the lily figure in a prefixed set of opposites established by hegemonic forces. That is why the apparent ambiguity in Jenny is solved from the beginning and, although she is represented as a fallen woman, she is, in fact, just a variation on the theme of the angel in the house. Swinburne's women have a type of ambiguity that is constantly clashing and, therefore, they are sites of never-ending signification. In Kristevan terms, Swinburne's women are semiotic rather than symbolic, whereas Dante Gabriel Rossetti's women are symbolic.

Kristevan semiotics, asserts Toril Moi, "emphasizes the marginal and the heterogenous as that which can subvert the central structures of traditional linguistics" (161). Swinburne's poetry can be said to manifest marginal types of discourse, especially in "Dolores" and in "Anactoria." His portrayal of a sadomasochistic unchaste virgin and of a lesbian with destructivecreative impulses typifies Julia Kristeva's process of signification and Hélène Cixous's writing the body, both processes that aim at deconstructing the linear, goal-oriented language of patriarchy. Dolores is the embodiment of the goddess and the demoness. As a virgin, she is certainly an unorthodox one. Rather than a more joyful or pious type of virgin, the mystic and somber Dolores is Our Lady of Pain, a cruel patroness. Her physical description is utterly disturbing and points at the destruction and pain she is capable of inflicting: cold eyelids, heavy white limbs, hard eyes, cruel red mouth, lips full of lust and laughter, fangs, ravenous teeth. However, the effect she has on an acolyte is actually soothing as he urges her to "press with new lips where [she] pressed. For [his] heart too springs up at the pressure" (28-29), 
so that he could be filled with pleasure. By calling her Notre-Dame des Sept Douleurs, Swinburne mocks the authority of the Christian faith and shakes one of the pillars of patriarchal Western thought, the Church. Not God, but dark, pagan, overtly sexualized goddesses like Dolores, Astarte, and Venus, become the object of worship of fervent followers of a semiotic cult verbalized in what in Kristevan terms is the discourse of the illogic, the unconscious, the impulsive, the repressed, the transverbal, the atemporal [my translation] (Macaya 87). This discourse that usually manifests itself in the gaps and inconsistencies of the linear, rational language of patriarchy, surfaces in "Dolores" and in "Anactoria" as a language of the female body, that is, as what Cixousian critics have termed "écriture feminine ${ }^{3}$."

To Cixous, writing said to be feminine comes from the eroticization of the body. She explains that

\begin{abstract}
Almost everything is yet to be written by women about femininity: about their sexuality, that is, its infinite and mobile complexity, about their eroticization, sudden turn-ons of a certain minisculeimmense area of their bodies [. . .]. A woman's body with its thousand and one thresholds of ardor [. . .] will make the old single-grooved mother tongue reverberate with more than one language (885).
\end{abstract}

In this sense, Dolores' is a sexuality that celebrates transgression while it functions as a type of bodily, erotic discourse. Constant references to her body's transformative powers render it a site of "jouissance." One can imagine her "lips full of lust and of laughter" (25) curb in a sardonic smile as she blows, bends, and breaks the bodies of those willing to follow her to her "house of unquenchable fire" (23) and writhe but in ecstatic pangs: "Ah, feed me and fill me with pleasure,/ Ere pain come in turn" (31-32). Like female sexuality, writing said to be feminine is "a multiple and inexhaustible course with millions of encounters and transformations of the same into the other and into the in-between, from which woman takes her forms" (Cixous 883). In other words, it is multiple instead of single, diffuse instead of focused, oriented toward process instead of toward goals. Indeed, the structure of the poem is more diffuse and process-oriented, and the signs are multivalent. Unlike more readable types of poems such as ballads and narrative poetry, Swinburne's "Dolores" does not tell a story with a discernible beginning and a clear-cut end. On the contrary, the poem concentrates on extricating the different possible meanings of Dolores' body: "splendid and sterile" (71), "bitter and tender" (87), "sanguine and subtle" (103), "fierce and luxurious" (135), "my sister, my spouse, and my mother" (151), "sleepless and deadly" (215), "a goddess new-born" (336), "a mortal, a maiden/ A queen over death and the dead" (347-48), "Most fruitful and virginal, holy" (351). Instead of telling a linear, logical story about Dolores, those sets of contradictory meanings render her as a process of endless signification rather than as a Manichean type of ambiguity that is solved from the start. Finally, by stressing the multiple values of the female body, Swinburne writes and rewrites the body of Dolores giving it a different meaning each time. Thus, she has "cold eyelids" but they "hide like a jewel" (1). In the same way, hers are "Hard eyes," yet they "grow soft for an hour" (2); hers is the "bosom [that] no fasts could emaciate, / No hunger compel to complain/ Those lips that no bloodshed could satiate" (261). "The white wealth of [her] body [is] made whiter/ By the blushes of amorous blows" (267-68) because Dolores is "fed with eternal breath/ And alive after infinite changes" (58-59). Since this is a language that mimics the subversive laugh of an ultimately abnormal woman (in allusion to Cixous's groundbreaking homonym article, "The Laugh of the Medusa"), it is intended to "wreck partitions, classes, and rhetorics, regulations and codes" (886), in particular the lily/rose, angel/monster, Madonna/whore partitions and the rhetorics of Victorian sexuality with all its hypocritical regulations and codes.

"Anactoria" is Swinburne's celebration of homoerotic love and still another attempt at developing marginal discourses that spring from the female body. It is through a boundless, more often than not, violent ardor that Sappho's and Anactoria's bodies are able to go past the lily/rose constraint. As lesbians, neither one can fit into 
the conventional mother, wife or femme fatale roles that originate in biological circumstances. Thus, they stand in direct opposition to normalcy and, to a certain extent, represent what Cixous called the third body. The constant references to seemingly destructive actions like blinding, burning, dividing, severing, crushing, bruising, scourging, and consuming among many others in the lesbian sexual act, would point to an utterly destructive kind of love and a canceling out of each other; however, in accordance with Cixousian thought they actually "offer the gift of alterity, producing rather than reducing difference" (Bray 63). In "Anactoria," Sappho starts by urging the object of her love to see what the effects of that love have caused:

My life is bitter with thy love: thine eyes Blind me, thy tresses burn me, thy sharp sighs

Divide my flesh and spirit with soft sound, And my blood strengthens, and my veins abound. I pray thee sigh not, speak not, draw not breath; Let life burn down, and dream it is not death. (1-6)

A love like Anactoria's is so irreverent in the patriarchal world that it has the power to erase all traces of convention, and rather than in the logical language of the Father, this love is expressed in the transverbal language of the Mother. The great love between the women is then expressed through pulsations coming from the body. But in the process a strong clash between the bodies of Sappho and Anactoria must necessarily occur: "I feel thy blood against my blood: my pain/ Pains thee. And lips bruise lips, and vein stings vein" (1112). And so does the third body emerge, as "that which is created through the exchange, the flow, of desire" (Bray 64), but also as an unlawful entity that exists in "Anactoria" only as the product of the consummation of two female bodies rather than as the more conventional union of man and woman.

Like the dark and dis-eased pre-New Woman figure that Christina Rossetti sketched in some of her literary works, Swinburne's primordial women and terrible women offer a third possibility for the nineteenth-century women within the limits of the dominant sexual politics of the time. His marginal discourses, ambiguity, and never-ending signification are an expression of what Allison Pease calls the aesthetics of obscenity. Pease argues that the nineteenth century "inherited the oppositions between pornography and aesthetics that were created in the eighteenth century" (38). It is not until the sexual body is elevated to the status of art and included in the realm of legitimate culture that marginal, ambiguous, open-ended discourses like Swinburne's are normed. In stylizing "panting bodies typically associated with pornography," "sexually enumerated" bodies through "sexually suggestive quotes" (64$65)$ that, as Dante Gabriel Rossetti once worried, would "make a few not even particular hairs stand on end, to say nothing of other erections equally obvious" (qtd in Pease 38), Swinburne blurs the line between low and high culture, the erotically perverse and the properly decent, the aesthetically obscene and the distastefully lewd. In the process, his poetry (just like C.G. Rossetti's literary production) "represents what Raymond Williams calls residual and emergent culture, either of which stands outside of the dominant culture and must in some way be incorporated lest they continue to pose a threat" (Pease 64). Once again, abnormal discourses on sexuality get caught in an endless game of normalizing the unstable, the aberrant, the eccentric. The marginal illusively moves to the center, but is actually incorporated and blended into a "new" center and, thus, an essentializing hegemonic discourse on sexuality belies it.

New discourses on sexuality are necessary to create the illusion of progress and sociopolitical transformation. That is the history of sexuality since sex is a constant, and historically changing, deployment of discourses on sex-as both Foucault and Weeks would claim - but a carefully controlled deployment. As Hennessy argues in her chapter entitled "New Woman, New History," the discourse of the new is deceitful. The circulation in the social imaginary of "modes of thinking and desiring which had been thoroughly sanctioned in one ideological formation" must invariably be bridled and suppressed (1993, 104). A strategy of transference is called for, a 
transference that "allows the social order to be reproduced through times of social upheaval by being attached to 'new' ideas, signs, objects, or activities that pass through cultural censor of reformed public values" (104). C.G. Rossetti's and Swinburne's discourses on sexuality do not depart radically from D.G. Rossetti's. That is, they stop disrupting social conventions by negotiating the dual registers of new-ness, both voicing and suppressing oppositional discourses that make visible the contradictory social relations which patriarchal ideologies manage. That is how hegemony works.

Among the Pre-Raphaelites, their associates, and other poets who were influenced by them, the fallen woman figure took a variety of shapes. For Dante Gabriel Rossetti, the femme fatale was the epitome of his own eroticism, and as such she becomes merely an object of contemplation and a source of instant gratification. But for his sister, Christina, the femme fatale is the embodiment of a new type of woman who seeks internal enlightenment in spite of societal strictures. Nevertheless, overwhelmed by the pressure, Christina's revisions of the femme fatale turns out to reveal a strenuous inner struggle to come to terms with the decision to please none other than the self. Finally, Swinburne's portrayals of the femme fatale are those of women with an ambivalent set of values and ideals that cannot be judged by patriarchal standards: ambiguous matriarchal figures and female sexualities that are not inscribed within the Law of the Father but within the voice of the Mother. The three types of femme fatales certainly trace the evolution of Victorian thought among the Pre-Raphaelites and the Aesthetes, from Dante Gabriel Rossetti's sensous convention to Christina Rossetti's feminine audacity to Charles Algernon Swinburne's transgressive bohemianism. Nevertheless, the representations of rebellious female bodies point at a socio-political phenomenon, the interplay of sexual politics and the hegemonic regulation of discourses on sexuality that appear in times of crisis to counteract supposedly normative sexual practices. It is a fact that divergent conceptualizations of the female body circulated during the nineteenth century, but although disruptive they never managed to transform the status quo. Quite the contrary, the fin-de-siècle New Woman was an outgrowth of the Angel in the House and of the Fallen Woman.

\section{Notas}

1. See Eric Trudgill's Madonnas and Magdalens (1976), Stephen Marcus's The Other Victorians (1966), Peter T. Cominos's "Late Victorian Sexual Respectability and the Social System (1963), Ronald Pearsall's The Worm in the Bud (1969), Nancy Cott's "Passionless: an Interpretation of Victorian Sexual.

2. "During the years 1858-1860, Rossetti made several drawings of women famous for their beauty: Annie Miller, Ruth Herbert, Fanny Cornforth, Elizabeth Siddall, Jane Morris" (Grieve 20-1).

3. Cixous has always refused to refer to feminine writing or masculine writing. She prefers to make a distinction between writing said to be feminine or writing said to be masculine. Interview with Verena Andermatt Conley in Hélène Cixous: Writing the Feminine.

\section{Bibliography}

Barringer, Tim. (1999). Reading the PreRaphaelites. New Haven; London: Yale UP.

Bray, Abigail. (2004). Hélène Cixous: Writing and Sexual Difference. N.Y.: Palgrave Macmillan, .

Bullen, J. B. (1998). The Pre-Raphaelite Body: Fear and Desire in Painting, Poetry, and Criticism. Oxford: Clarendon.

Butler, Judith. (1993). Bodies that Matter: On the Discursive Limits of "Sex." New York: Routledge.

Casteras, Susan. (1987). Images of Victorian Womanhood in English Art. London: Associated UP.

Cixous, Hélène. (Summer 1976). "The Laugh of the Medusa." Signs: 875-99. 
Conley, Verena Andermatt. (1991). Hélène Cixous: Writing the Feminine. Lincoln: U of Nebraska P.

Davis, Lloyd, ed. (1993). Virginal Textuality and Textuality in Victorian Literature. N.Y.: State U of New York P.

Foucault, Michel. (1978). The History of Sexuality. Vol.1. N.Y.: Pantheon.

Gilbert, Sandra., Gubar, Susan. (1984). The Madwoman in the Attic: The Woman Writer and the Nineteenth Century Literary Imagination. New Haven: Yale UP.

Grieve, Alastair. (1999). "Rossetti and the Scandal of Art for Art's Sake in the Early 1860s." After the Pre-Raphaelites: Art and Aestheticism in Victorian England. Ed. Elizabeth Prettejohn. New Brunswick: Rutgers UP.

Hennessy, Rosemary. (1993). Materialist Feminism and the Politics of Discourse. N.Y.: Routledge, .

(2000). Profit and Pleasure: Sexual Identities in Late Capitalism. New York: Routledge, .

Kristeva, Julia. (1980). Desire in Language: A Semiotic Approach to Literature and Art. Oxford: Blackwell.
Lang, Cecil Y. (1975). The Pre-Raphaelites and Their Circle. $2^{\text {nd }}$ ed. Chicago; London: U of Chicago P.

Macaya, Emilia. (1992). Cuando estalla el silencio: para una lectura femenina de textos hispánicos. San José, Costa Rica: Editorial de la Universidad de Costa Rica.

Marsh, Jan. (1994). Christina Rossetti: A Literary Biography. London: Jonathan Cape. , ed. (1994). Poems and Prose. Christina Rossetti. London: Everyman.

(1987). Pre-Raphaelite Women: Images of Femininity. New York: Harmony.

Miller, Andre H., Adams, James Eli, eds. (1996). Sexualities in Victorian Britain. Bloomington: Indiana UP.

Moi, Toril, ed. (1985). Sexual/Textual Politics: Feminist Literary Theory. London: Methuen.

Pease, Allison. (2000). Modernism, Mass Culture, and the Aesthetics of Obscenity. Cambridge: Cambridge UP.

Showalter, Elaine. (1985). The Female Malady: Women, Madness and English Culture 1830-1980. N.Y.: Pantheon.

Weeks, Jeffrey. (1981). Sex, Politics and Society: The Regulation of Sexuality since 1800. London: Longman.

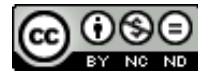

Este obra está bajo una licencia de Creative Commons Reconocimiento-NoComercial-SinObraDerivada 4.0 Internacional. 